\title{
Assessment of the Bacteriological Quality of Minced Meat and Beef Burger at Selected Egyptian Hypermarkets
}

\author{
Abdelrahman, H.A. ${ }^{\text {a }}$; Ismail, S.A.S. ${ }^{\text {a }}$; Harydi, A.M. ${ }^{\text {b }}$ \\ a: Professors of Meat Hygiene; Fac .of Vet Med.; Suez Canal \\ University b: Head of Microbiology Department; GOEIC-Food \\ Safety lab.; Port-Said; Egypt.
}

\begin{abstract}
This study was carried out to assess the bacteriological quality of minced meat and beef burger marketed at a selected number of hypermarkets in Egypt. A total of 100 minced meat and beef burger (50 samples for each) samples were randomly collected. The mean total aerobic bacteria counts were $9.3 \times 10^{5} \pm 3 \times 10^{4}$ and $8.8 \times 10^{5} \pm 4 \times 10^{4} \mathrm{cfu} / \mathrm{g}$. for Staphylococcus aureus counts were $2.1 \times 10^{2} \pm 2 \times 10$ and $3.7 \times 10^{2} \pm 5 \times 10 \mathrm{cfu} / \mathrm{g}$ respectively. Salmonella was detected in $3(6 \%)$ and 15 $(30 \%)$; of minced meat and Beef burger respectively. Clostridium perfringens was detected in $8(16 \%)$ and 23 (46\%) of the minced meat and beef burger samples respectively. Listeria monocytogenes and Shigella spp. failed to be detected in the samples under investigation. It was concluded that there were inadequate sanitary and hygienic measures during all steps of production of minced meat and beef burger at the selected hypermarkets .Good hygienic practices must be applied to improve the quality and safety of the products
\end{abstract}

\section{Introduction}

There are great human health risk due to foodborne illness which ranging from a longstanding disease to fetal one specially in persons suffering from immune deficiency problems. The significante importance of different foodborne illness varies between countries depending on the type of foods consumed, technology of processing, methods of handling and storage, in addition to the age and immunity of the consumer (ICMSF, 2002). The repaid development in meat technology has been easier to produce a wide variety of meat products. The 
bacteriological quality of the processed meat products depends on the bacteriological profile of the raw meat used in processing, the hygienic condition adopted during manufacturing steps, and on the type of packaging and storage techniques (Ínal, 1992).

During slaughter and processing of the animals, the carcasses are contaminated with a wide variety of microorganisms from different origins. Meat and meat products are considered a source of risks for pathogenic species of bacteria such as Clostridium perfringens, Escherichia coli, Staphylococcus aureus, and Salmonella (İnal, 1992). Consequently it may threaten human health.

The high occurrence of diarrheal illness in developing countries suggests the fundamentals food safety problems. Meat and meat products can lead to public health hazards when they are subjected to contamination with harmful microorganisms due to neglected hygienic measure with bad hygienic practices, mishandling and improper storage (WHO, 2009).

This study was carried out to evaluate the bacteriological quality of minced meat and beef burger sold at selected hypermarkets in Egypt.

\section{Materials and methods}

Samples collection: A total of 50 chilled minced meat and 50 beef burger samples were randomly collected on the same day of production from the selected hypermarkets outlets in Egypt, and transferred to the laboratory in icebox container and examined bacteriologically on the same day.

\section{Preparation of samples:}

For enumeration methods; 10 $\mathrm{g}$ from each of the examined minced meat and beef burger samples were weighted and mixed with $90 \mathrm{ml}$ of sterile $0.1 \%$ pepton water into a sterile stomacher bag, then homogenized in stomacher for 2 minutes to obtain a dilution rate of $\left(10^{-1}\right)$. From the original homogenate a decimal serial dilutions of up to $10^{-6}$ were carried out.

For Detection methods $25 \mathrm{~g}$ from the prepared samples were added to $225 \mathrm{ml}$ of the sterile buffered peptone water incubate at $37^{\circ} \mathrm{C}$ for 24 hours then plating on specific media violet red bile lactose agar for E.coli or in enrichment in Rappaport Vassliliadis broth medium for Salmonella then plating on XLD medium.

\section{Bacteriological examinations:}


1. Aerobic plate bacterial counts were carried out according to (ISO/FIDS 4833:2013).

2. Staphylococcus aureus was cultured on Baird-Parker agar supplemented with tellurite egg yolk emulsion. (ISO/FDIS 6888-1:1999).

3. Detection of Salmonella, Listeria monocytogenes, Shigella spp., and Clostridium perfringens were detected according to (ISO 6579:2002) - (ISO 112901:1996) (ISO/FDIS 21567:2004) (ISO/FDIS 7937:2004), respectively.

Statistical Analysis: was done by T-test using SPSS Software 13.0.

\section{Results and Discussion}

Even if the meat has been obtained from a healthy slaughtered animal, it may be subjected to various degrees of bacterial contamination during processing, or during storage, packaging, and or marketing (İnal, 1992). Total aerobic bacteria count is taken as a measure tool for microbial quality of the meat. The results represented in Table (1) revealed that the mean total aerobic bacteria were $9.3 \times 10^{5} \pm 3 \times 10^{4}$ and $8.8 \times 10^{5} \pm 4 \times 10^{4} \mathrm{cfu} / \mathrm{g}$ for minced and beef burger, respectively. According to Egyptian standard 1688/2005,
$(56 \%)$ and $(60 \%)$ of minced and beef burger samples exceeded the acceptable limits $\left(10^{6} \mathrm{CFU} / \mathrm{g}\right.$ and $\left.10^{5} \mathrm{CFU} / \mathrm{g}\right), \quad$ respectively. Lower values of aerobic plate count in this study were recorded; Sancak et al. (1993) found that $2.3 \times 10^{5}$ to $1.4 \times 10^{10}$, Gonulalan and Kose (2003) $7.4 \times 10^{5}$ to 5.3 $\times 10^{9}$, and Başkaya et al, (2004) recorded a count of $3.1 \times 10^{4}$ to $6.3 \times 10^{7} \mathrm{cfu} / \mathrm{g}$.

Staphylococcus

aureus

count: Staphylococci, which are occurs naturally on skin and mucous membranes of human and animals, it contaminate the meat by several ways. The results obtained in Table (1) revealed that the mean Staphylococcus aureus counts in minced and beef burger were $2.1 \times 10^{2} \pm$ $2 \times 10$ and $3.7 \times 10^{2} \pm 5 \times 10$ $\mathrm{cfu} / \mathrm{g}, \quad$ respectively. According to the Egyptian standards limits $\left(\leq 10^{2} \mathrm{CFU} / \mathrm{g}\right)$, $(64 \%)$ and $(78 \%)$ of minced meat and beef burgers, respectively were unacceptable. Higher values of $S$. aureus than in current study have been reported by Sancak et al. (1993), Gonulalan and Kose (2003), and Başkaya et al. (2004), $9.2 \times 10^{6}, 6.7 \times 10^{6}$, and $8.2 \times$ $10^{3}$ respectively.

Clostridium perfringens: Table (2) revealed that out of 
50 samples $C L$. perfringens was detected in (16) \% and (46) $\%$ of minced and beef burgers, respectively. Gokmen et al. (2003) reported similar results $(15 \%)$ in minced meat samples. Ashraf et al. (2015) reported (16.67\%) in both minced meat and beef burgers samples.

Salmonella: The results given in Table (2) showed that Salmonella was found to be positive in (6) \% and (30) $\%$ of minced and beef burgers samples, respectively and according to the EOS specifications were considered un-acceptable. High results of Salmonella in beef burgers can be explained by contaminated raw materials, extra manipulation and additives in beef burger manufacturing. Higher results to the current study (11\%) in minced meat samples were reported by Başkaya et al. (2004). Meanwhile, Hinton et al. (1998) failed to detect Salmonella in 99 frozen minced meat samples. $L$. monocytogenes and Shigella spp. failed to be detected in the examined samples of minced and beef burger (Table 2). Gokmen et al. (2003) reported a higher result $(22 \%)$ of Listeria monocytogenes in the examined minced meat samples.

Meanwhile, Wong et al (2012) reported $22.9 \%$ and Gokben et al. (2012) reported $5.7 \% \quad$ Listeria monocytogenes in the examined beef burger samples.

Table (1): The total bacterial and Staphylococcus aureus counts with the number of rejected samples percentage

\begin{tabular}{|c|c|c|c|c|}
\hline \multirow{2}{*}{} & \multicolumn{2}{|c|}{ Minced meat } & \multicolumn{2}{c|}{ Beef burger } \\
\cline { 2 - 5 } & Mean \pm S.D & $\%$ & Mean \pm S.D & $\%$ \\
\hline \multirow{2}{*}{ Total bacterial count } & $\begin{array}{c}9.3 \times 10^{5} \pm \\
3 \times 10^{4}\end{array}$ & $28(56)$ & $\begin{array}{c}8.8 \times 10^{5} \pm \\
4 \times 10^{4}\end{array}$ & $30(60)$ \\
\hline Staphylococcus aureus & $\begin{array}{c}2.1 \times 10^{2} \pm \\
2 \times 10\end{array}$ & $32(64)$ & $\begin{array}{c}3.7 \times 10^{2} \pm \\
5 \times 10\end{array}$ & $39(78)$ \\
\hline
\end{tabular}


Table (2): The number of rejected samples in the examined minced meat and beef burger samples.

\begin{tabular}{|l|c|c|c|c|}
\hline & Cl.perfringens & L.monocytogenes & $\begin{array}{c}\text { Salmonella } \\
\text { spp. }\end{array}$ & $\begin{array}{c}\text { Shigella } \\
\text { spp. }\end{array}$ \\
\hline Minced meat & $8(16 \%)$ & $0(0)$ & $3(6 \%)$ & $0(0)$ \\
\hline Beef burger & $23(46 \%)$ & $0(0)$ & $15(30 \%)$ & $0(0)$ \\
\hline
\end{tabular}

\section{Conclusion:}

The results obtained in this study indicated that the bacteriological quality of minced meat and beef burger at hypermarkets in Egypt ranges from a moderate to low. As high aerobic plate count negatively influences the quality and shelf life of the examined products. The presence of Staphylococcus aureus and $C$. perfringens indicated improper hygienic practice and posed a risk to consumer safety. In addition, the detection of a prominent biological hazard like Salmonella stated the presence of high risk cross contamination and a failure in minced and beef burger manufacturing hygiene system. In order to produce high quality minced and beef burger in compliance with the Egyptian standard, it is necessary to apply the Good Manufacturing and Good Hygienic practices during processing and distribution.

\section{Acknowledgements}

The authors are thankful to the Director, GOEIC - food safety lab.- for providing necessary facilities for this study.

\section{References}

Ashraf, A.; Fatma, I. E.; Dalia F. K. and Mohamed A. M. (2015): Typing of Clostridium perfringens isolated from some meat products by using PCR. Benha Veterinary Medical Journal, vol. 29, no. 1:118123.

Başkaya, R.; Karaca, T.; Sevinc, I.; Cakmak, O.; Yıldız, A. and Yoruk, M. (2004): The histological, microbiological and serological quality of ground beef marketed in İstanbul. Yuzuncu Yil Univ. Vet. Fak. Derg.; 15: 41-46.

Egyptian Official Standards (2005): beef burger EOS/1688:2005, Egyptian Organization for 
Standardization,

Egypt.

Egyptian Official Standards (2005): minced meat EOS/1694:2005, Egyptian Organization Standardization, Cairo, Egypt.

Gokmen, M. and Alişarlı, M. (2003): Investigation of some pathogenic microorganisms in minced meat consumed in Van. Yuzuncu Y1l Univ. Vet. Fak. Derg., 2003; 14: 27-34. Gonulalan, Z. and Kose, A. (2003): Microbiological quality of ground beef retailed in Kayseri. Firat Univ. Să̆. Bil. Vet. Derg., 2003; 17: 49-53.

Gokben Ozbey, Abdulkasim Icyeroglu and Adile Muz (2013): Prevalence of Listeria species in raw hamburger meat balls and chicken burgers in eastern Turkey. African Journal of Microbiology Research Vol. 7(31), pp. 4055-4058.

Hinton, M.; Coombs, E.; Tucker, V.; Jones, S.; Allen, V.; Hudson, W.R. and Corry, J.E.L.(1996): The bacteriological quality of British beef 2. Frozen minced beef. Meat Sci., 50: 395-402.

ICMSF

Commission (International Microbiological

Specifications for Foods). (2002): Microorganisms in Foods 7. Microbiological
Testing in Food Safety Management. New York: Kluwer Academic/ Plenum Publishers.

İnal, T. (1992): Besin Hijyeni (Hayvansal Gidaların Sağlik Kontrolu). İkinci Bask1, Final Ofset, İstanbul,; 9-10.

ISO (1996): Horizontal method for the detection and enumeration of Listeria monocytogenes Part 1: Detection method. ISO 11290-1 (E), Geneva, Switzerland.

ISO (1999): Horizontal method for the enumeration of coagulase positive Staphylococcus

(Staphylococcus aureus and other species), Part 1: Technique using Barid Parker Agar medium. ISO/FDIS 6888-1: (E), Geneva, Switzerland.

ISO (2002): Horizontal method for the detection of Salmonella spp. ISO 6579: (E), Geneva, Switzerland

ISO (2004a): Horizontal method for the detection of Shigella spp. ISO/FDIS 21567 (E), Geneva, Switzerland.

ISO (2004b): Horizontal methods for Enumeration of Clostridium perfringens. ISO/FDIS 7937 (E), Geneva, Switzerland.

ISO (2013): Horizontal method for the enumeration of micro-organisms, colony 
count technique at $30^{\circ}$. and Projects of WHO.

ISO/FDIS 4833: (2013) (E),

Geneva, Switzerland.

Sancak, Y.C.; Boynukara, B. and Ăgaoğlu, S. (1993): The microbiological quality of ground meat marketed in Van. Yuzuncu Y1l Univ. Vet. Fak. Derg., 4: 73-86.

WHO (2009): Food safety and food borne illness.

Factsheets of the Programs http://www.who.int/mediacentre/f actsheets/fs237/en/.

Wong, W. C.; Pui, C. F.; Tunung, R.; Cheah, Y. K.; Nakaguchi. Y.; Nishibuchi, $M$. and Son, R. (2012): Prevalence of Listeria monocytogenes in frozen burger patties in Malaysia. International Food Research Journal 19(4): 1751-1756.

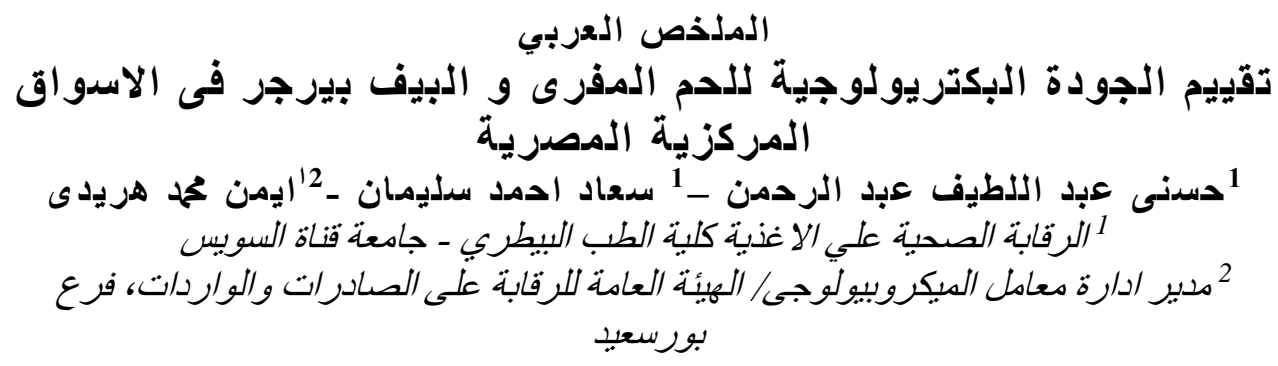

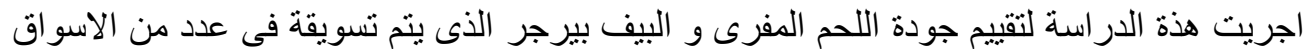

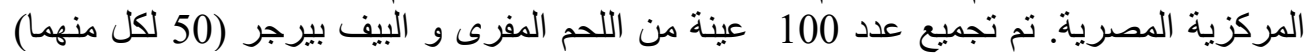

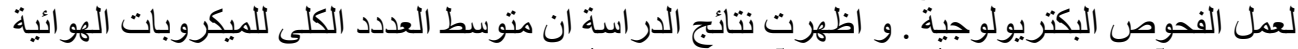
كان

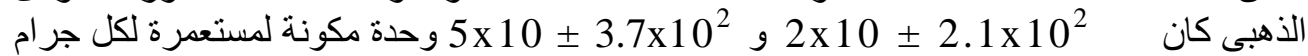

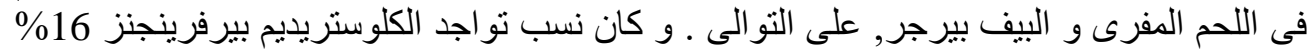

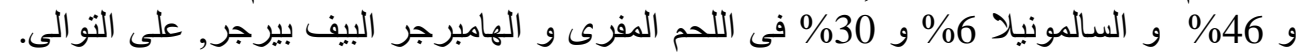

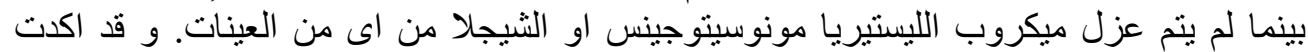

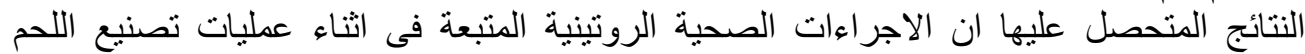

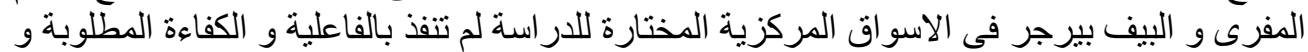

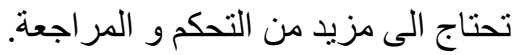

